\title{
The Wheeling Bridge Exception: Reopening Executory Judgments of Article III Courts
}

\author{
Heather L. Nevin $\dagger$
}

The Framers believed the separation of powers in our tripartite government structure to be essential to prevent tyranny. ${ }^{1}$ Hence, all legislative powers are vested in Congress, ${ }^{2}$ the executive power is vested in the President, ${ }^{3}$ and the judicial power is vested in "one supreme Court, and in such inferior Courts as the Congress may from time to time ordain and establish." The branches are not rigidly separated, however, as the Framers believed that each branch must have some control over the others in order to maintain a free government. Therefore, the Constitution has a built-in system of checks and balances.

The Framers were especially concerned with hemming in the power of the legislature. To achieve this end, the language of the Constitution explicitly gives the Executive several checks on the legislature's power. The Framers also ensured that the judicial branch would be insulated from political pressure by giving federal judges life tenure and guaranteeing their salaries." Although the Framers did not write any other explicit protections for the judiciary against the legis-

$\dagger$ B.A. 1993, Williams College; J.D. Candidate 2000, The University of Chicago.

I See Federalist 47 (Madison), in Clinton Rossiter, ed, The Federalist Papers 301 (Mentor 1961) ("The accumulation of all powers, legislative, executive, and judiciary, in the same hands, whether of one, a few, or many, and whether hereditary, self-appointed, or elective, may justly be pronounced the very definition of tyranny.").

2 US Const Art I, $\$ 1$.

3 US Const Art II, \& 1.

4 US Const Art III, $\$ 1$.

5 See Federalist 48 (Madison), in Rossiter, ed, The Federalist Papers at 308 (cited in note 1) (stating that "unless these departments be so far connected and blended as to give to each a constitutional control over the others, the degree of separation which the maxim requires, as essential to a free government, can never in practice be duly maintained").

6 For example, no law may be enacted by the legislature without allowing the President an opportunity to veto. US Const Art I, \& 7, cl 2. On the other hand, the Senate must consent to presidential appointments. US Const Art II, $\$ 2, \mathrm{cl} 2$.

7 See Federalist 48 (Madison), in Rossiter, ed, The Federalist Papers at 309 (cited in note 1) ("The legislative department is everywhere extending the sphere of its activity and drawing all power into its impetuous vortex.").

8 For example, while Congress is the only branch that can declare war, US Const Art I, $\S 8$, cl 11, the Executive operates as the Commander-in-Chief of the armed forces. US Const Art II, $\$ 2$, cl 1 . See also note 6 .

9 US Const Art III, $\$ 1$. 
lature into the Constitution, ${ }^{10}$ the independence of the judiciary was fundamental to the Framers' conception of our constitutional framework. ${ }^{11}$

Central to this idea of judicial independence is the prohibition against Congress enacting legislation that reopens the final judgment of an Article III court. ${ }^{12}$ By reopening a final judgment, Congress exercises judicial power, thereby violating the vesting clause of Article III and intruding on the judicial branch's function. A recent Supreme Court decision, Plaut $v$ Spendthrift Farm, Inc, ${ }^{13}$ affirmed this rule, while at the same time, in a brief aside, recognizing an exception for judgments with prospective effects. ${ }^{14}$ The exception dates back to an 1855 Supreme Court case, Pennsylvania $v$ Wheeling and Belmont Bridge $\mathrm{Co}$, ${ }^{15}$ but in the intervening one hundred and forty years, courts have struggled to explain why and when this exception applies.

Having a clear understanding of the scope of the "Wheeling Bridge exception" is vitally important for both courts and potential litigants today. As the judicial system becomes increasingly overburdened by litigation, both courts and parties have an incentive to use consent decrees as a way of saving time and money. However, if a consent decree falls within the scope of Wheeling Bridge, Congress may

10 The Constitution does put direct prohibitions on the power of the legislature that the judiciary may enforce through judicial review. For example, Article I contains two independent bars against retroactive legislation. The Ex Post Facto Clause prohibits retroactive application of penal legislation, and the prohibition on bills of attainder prevents Congress from summarily punishing individuals for past conduct. US Const Art I, $\S 9, \mathrm{cl} 3$. The Takings Clause prevents Congress from depriving persons of private property for "public use" except upon payment of "just compensation." US Const Amend V. Congress also may not legislate to deprive a person of "life, liberty, or property, without due process of law." Id.

11 See Federalist 47 (Madison), in Rossiter, ed, The Federalist Papers at 303 (cited in note 1) ("Were the power of judging joined with the legislative, the life and liberty of the subject would be exposed to arbitrary control, for the judge would then be the legislator. Were it joined to the executive power, the judge might behave with all the violence of an oppressor.").

12 See Federalist 81 (Hamilton), in Rossiter, ed, The Federalist Papers at 484 (cited in note 1) ("A legislature, without exceeding its province, cannot reverse a determination once made in a particular case; though it may prescribe a new rule for future cases.").

13514 US 211 (1995) (holding that a retroactive amendment to the Securities Exchange Act of 1934 violated separation of powers doctrine because it required federal courts to reopen final judgments).

14 Id at 232 (noting that nothing in the Court's holding calls into question that Congress may legislate to alter the "prospective effects of injunctions entered by Article III Courts").

1559 US (18 How) 421, 430-32 (1855) ("Wheeling Bridge II") (holding that it was within Congress's power to legalize a bridge retroactively, in spite of the Court's earlier decree that the bridge be raised to a certain height or removed). There were two cases concerning the Wheeling Bridge. The first case, Pennsylvania $v$ Wheeling and Belmont Bridge Co, 54 US (13 How) 518 (1851) ("Wheeling Bridge I"), held that Virginia's construction of a bridge over the Ohio River was an unlawful obstruction of navigation. The second case, Wheeling Bridge $I I$, is the source of the Wheeling Bridge exception. This Comment uses the terms "Wheeling Bridge" and "Wheeling Bridge exception" to refer to the second case, except when the history of the Wheeling Bridge exception is explained in Part I.A. 
legislate to overrule it. This would act as a huge qualifier to any deal that parties to the decree are willing to make. Similarly, once a court has approved a consent decree, both the court and the parties need to know under what circumstances that deal may no longer be enforced.

Although at first cut the Wheeling Bridge exception may seem to condone unwarranted legislative intrusion on the judicial function, this Comment argues that the exception is necessary to preserve one of the Constitution's underlying values-equality before the law. At any given time, all people must be subject to the same laws. In order to ensure this equality, two results must follow: first, Congress must not be allowed to overrule an Article III court's judgment when that judgment governs solely past conduct; second, Congress must be allowed to reopen an Article III court's judgment when that judgment governs future conduct.

Allowing Congress to overrule a court's judgment when that judgment governs only the parties' past conduct would violate the principle that all parties must be subject to the same law at any one time. For example, suppose there is a federal law requiring all bridges across the Ohio River to be built at a certain minimum height above the high water mark. Both Jones and Brown want to build bridges across the river that do not meet this minimum height requirement. Brown is deterred by the fear of legal liability and builds his bridge at the minimum specified height. Jones goes ahead and builds his bridge below the minimum height required. Because Jones's bridge is too low, Smith, a shipper, cannot get his ships up the river anymore. Smith sues Jones for damages in federal district court, and the court awards Smith the appropriate damages.

One month later, Congress amends the height requirement for bridges across the Ohio River in order to allow bridges built at the height of Jones's bridge. Furthermore, Congress requires the legislation to be applied retroactively. Congress has now declared the past conduct of Jones to be legal. In effect though, the law only retroactively applies to parties that had controversies adjudicated by the court. Brown, who would have liked to build his bridge at a lower height, does not benefit from the change in law as there is no way for Brown to go back in time and change his prior behavior. ${ }^{16}$ Jones and Brown are not equal before the law. Jones's actions are governed by the congressional amendment, while Brown's actions are still governed by the former version of the law. Congress reached back in time and immunized a specific party, Jones, from his actions-actions that Jones knew to be in violation of the law at the time the bridge was

16 In addition, Smith must pay back to Jones the previously awarded damages, raising finality issues that are outside the scope of this Comment. 
built. Because retroactive legislation raises these fairness considerations, the Supreme Court has traditionally been hostile to it, ${ }^{17}$ and Plaut confirms its unconstitutionality. ${ }^{18}$

When a court's judgment concerns future conduct, the opposite rule takes effect: Congress must be allowed to reopen the final judgment of the court in order to ensure all parties are subject to the same law going forward in time. Going back to the bridge example, suppose there is no federal law specifying the minimum bridge height but that Smith does not want Jones to build a bridge at height $\mathrm{H}$ across a river, because Smith believes the bridge will be too low, resulting in the river's obstruction. Smith goes to a federal district court and obtains an injunction against Jones, forbidding Jones to build the bridge at height $\mathrm{H}$ or lower. ${ }^{19}$ One month later, Congress passes a law that states bridges need only be built at height $\mathrm{H}$. Without the Wheeling Bridge exception, Jones is stuck. The injunction forbids Jones from building the bridge at height $\mathrm{H}$, while a third party, say Brown, may legally do so. Jones and Brown are subject to different laws. Jones is prevented from building the bridge at height $\mathrm{H}$ by the injunction, while Brown is allowed to build the same exact bridge under an act of Congress. This is the result the Wheeling Bridge exception seeks to avoid.

Therefore, when a court's judgment concerns only past conduct, Congress is not allowed to overrule it. However, when a court's judgment concerns future conduct, the rule flips-Congress must be allowed to reopen executory judgments in order to bring those judgments in line with changes in the law. Together, Wheeling Bridge and Plaut act as a check between the legislative and judicial branches, as neither branch is allowed to immunize parties from current law.

Because the Wheeling Bridge exception promotes this important constitutional goal, this Comment argues that it should be applied to any judgment with executory effects. This differs from the Wheeling Bridge opinion's approach, which suggested that not only must the judgment have executory effects, but that the case must involve "public rights" in order for the exception to apply. This Comment rejects the public rights distinction as part of the test, because "public rights" is an unstable category that does nothing to further the exception's underlying constitutional goal-promoting equality before the law.

17 Landgraf v USI Film Products, 511 US 244, 265 (1994) (noting that the "presumption against retroactive legislation is deeply rooted in [Supreme Court] jurisprudence"). See also the discussion in Part II.B.

18 Plaut, 514 US at 225 (stating that "legislation that prescribes what the law was at an earlier time, when the act whose effect is controlled by the legislation occurred ... exceeds the powers of Congress").

19 The facts of this example are roughly based on Wheeling Bridge I. See note 15.

20 Wheeling Bridge II, 59 US (18 How) at 431. 
Part I of this Comment lays out the relevant case law surrounding the Wheeling Bridge decision. Part II contends that by promoting equality before the law, the Wheeling Bridge exception conforms to the underlying goal of separation of powers doctrine-a government free from tyranny. Part III then argues that the Wheeling Bridge exception should apply whenever a judgment has executory effects and Congress's legislation does not violate any independent constitutional bar, whether or not the case involves public rights.

\section{THE DEVELOPMENT OfTHE WHEELING BRIDGE EXCEPTION}

\section{A. The Wheeling Bridge Cases}

The Wheeling Bridge cases arose out of the competing efforts of Pennsylvania and Virginia to have the Cumberland Road, a major highway of the day, built within their respective state lines at the point where the highway crossed the Ohio River. ${ }^{21}$ The Virginia legislature acted first, chartering a corporation to build a bridge across the river in 1847; this led to the first suit between the parties. In the first Wheeling Bridge case ("Wheeling Bridge I"), ${ }^{2}$ Pennsylvania sued to enjoin the Virginia corporation from building the bridge. ${ }^{23}$ However, as the bridge was completed by the time the case was argued, the Court held that the bridge "obstructs the navigation of the Ohio" and ordered the bridge raised to a certain height or removed. ${ }^{24}$ Virginia looked to Congress for help and, in a rider to a post office appropriations bill, Congress declared the bridge to be a "lawful structure[ ]" and that a post-road could be maintained at its current "site and elevation." "After the bridge collapsed in 1854, Pennsylvania sued to enjoin its reconstruction on the ground that an act of Congress cannot annul the final judgment of an Article III court. ${ }^{26}$ In Wheeling Bridge $I I$, the Court held that it was within Congress' power to legalize the bridge retroactively, in spite of the Court's earlier decree that the bridge be raised or removed. ${ }^{20}$

Writing for the majority in Wheeling Bridge II, Justice Nelson gave three reasons to justify the Court's result. First, as a threshold matter, Congress had the power to establish post-roads and to regulate the navigation of the Ohio River under the enumerated powers of

21 See Carl B. Swisher, 5 History of Supreme Court of the United States 408-19 (Macmillan 1974) (describing the history of litigation between the parties and the issues the Justices discussed in deciding the Wheeling Bridge cases).

22 Pennsylvania $v$ Wheeling and Belmont Bridge Co, 54 US (13 How) 518 (1851).

23 Id at 522.

24 Id at 578

25 Wheeling Bridge II, 59 US (18 How) at 426.

26 Id at 431 .

27 Id at $430-32$. 
Article $\mathrm{I}^{28}$ Second, Nelson argued that although Congress cannot legislate to annul a final judgment, "especially as it respects adjudication upon the private rights of parties," the current case was distinguishable because interference with the free navigation of the river dealt with a "public right common to all.", Nowhere in the opinion is "public right" defined. Finally, Nelson employed a distinction between legal and equitable remedies:

[I]f the remedy in this case had been an action at law, and a judgment rendered in favor of the plaintiff for damages, the right to these would have passed beyond the reach of the power of congress. It would have depended, not upon the public right of the free navigation of the river, but upon the judgment of the court. $^{30}$

However, since the judgment in this case was "executory, a continuing decree," Congress's legislation reopening the judgment was constitutional." The Court even went so far as to say that since the bridge had been declared lawful by Congress, "[ $\mathrm{t}]$ here is no longer any interference with the enjoyment of the public right inconsistent with law, no more than there would be where the plaintiff himself had consented to it.",32 Notably, however, the Court sustained the Wheeling Bridge $I$ judgment with respect to the award of costs to Pennsylvania."

Nelson gave no explanation for why Congress legislating to reopen an executory judgment passes constitutional muster, while disturbing a judgment in an action at law would not. Furthermore, the contours of this exception are unclear. The Wheeling Bridge II decision did not give courts any guidance on how to define "public rights" or how to balance the public/private and legal/equitable lines of analysis. Should the exception only apply to public rights in equitable actions or is one factor dispositive?

\section{B. The Plaut Decision: Affirming the Vitality of Wheeling Bridge}

In the almost one hundred and fifty years since Wheeling Bridge was decided, courts have struggled to determine why and when the

28 Id at 430-31. For Congress's power to establish postroads, see US Const Art I, $\$ 8, \mathrm{cl} 7$ (Congress shall have the power "[t]o establish Post Offices and post Roads"). Justice Nelson believed Congress had the power to regulate the navigation of rivers under the Commerce Clause, US Const Art I, \& 8, cl 3 .

29 Wheeling Bridge II, 59 US (18 How) at 431.

30 Id.

31 Id.

32 Id at 432.

33 Id at 436 . The Court's decision to sustain the award of costs to Pennsylvania is notable because it suggests that Justice Nelson did not think that the public rights factor standing alone was enough to require application of the Wheeling Bridge exception. See Part III.B. 
"Wheeling Bridge exception" should apply to the prohibition against Congress reopening final judgments of Article III courts. The Supreme Court has applied the exception in later cases, but has been inconsistent in its reasoning. In some cases, the public/private rights distinction has been dispositive, while in others the legal/equitable analysis has been given more weight. ${ }^{34}$ As a result, lower courts' reasoning has been similarly inconsistent. ${ }^{35^{\circ}}$

The recent Supreme Court decision of Plaut v Spendthrift Farm, Inc affirmed the rule that Congress cannot reopen the final judgments of Article III courts. ${ }^{36}$ Plaut overturned a retroactive amendment to the Securities Exchange Act of 1934 ("SEA") designed to reinstate claims that had been unexpectedly dismissed. ${ }^{38}$ The road to Plaut began with a case the Court decided four years earlier, involving the statute of limitations for actions under Section 10(b) of the SEA. ${ }^{39}$ The

34 Compare Hodges $v$ Snyder, 261 US 600, 604 (1923) (holding act of Congress consolidating several school districts constitutional even though the Supreme Court had previously permanently enjoined the consolidation, because the power to create and alter school districts is a public right); The Clinton Bridge, 77 US (10 Wall) 454, 462-63 (1870) (upholding act of Congress declaring bridge lawful even though a suit involving a public right of action to enjoin the building of the bridge was still pending); with System Federation No 91, Railway Employees' Department, AFL-CIO v Wright, 364 US 642,648-50 (1961) (reasoning that the District Court had the power, based on Wheeling Bridge, to modify an injunction from a consent decree between the railway and its nonunion employees after Congress amended the underlying law in the Railway Labor Act).

35 Compare Georgia Association of Retarded Citizens $v$ McDaniel, 855 F2d 805, 812 (11th Cir 1988) (arguing that a judgment was not subject to the Wheeling Bridge exception because it did not "concern a public right" nor "one which was the subject of an equitable decree"); Daylo $v$ Administrator of Veterans' Affairs, 501 F2d 811, 818 (DC Cir 1974) (holding damages judgment immune from congressional alteration and distinguishing Wheeling Bridge $I I$ as a case about "public rights"); with Imprisoned Citizen Union v Ridge, 169 F3d 178, 186 (3d Cir 1999) (arguing that Wheeling Bridge "did not hinge on the distinction between public and private rights" but instead "focused on the difference between prospective injunctive relief and judgments for damages"); Mount Graham Coalition v Thomas, 89 F3d 554, 556-57 (9th Cir 1996) (holding that legislation authorizing particular area as site for telescope project did not violate separation of powers by overturning injunction to stop the project); McGrath v Potash, 199 F2d 166, 167-68 (DC Cir 1952) (vacating injunction against deportation hearings because Congress had removed the statutory basis for such injunction); Western Union Telegraph Co v International Brotherhood of Electrical Workers, $133 \mathrm{~F} 2 \mathrm{~d}$ 955, 958 (7th Cir 1943) (quoting Wheeling Bridge as precedent for requiring court to modify injunction when Congress had changed underlying law). See also Ladner $v$ Siegel, $298 \mathrm{~Pa} 487,148$ A 699, 703 (1930) (using Wheeling Bridge as precedent for idea that an injunction does not create any "vested right[s]" in holder and thereby injunction remains vulnerable to modification).

36 Plaut, 514 US at 240 (stating that the Constitution's separation of powers denies Congress the authority to enact "retroactive legislation requiring an Article III court to set aside a final judgment").

3715 USC $\$ \$ 78$ a et seq (1994 \& Supp 1998).

38 Federal Deposit Insurance Corporation Improvement Act of 1991, Pub L No 102-242, 105 Stat 2236, 2387, codified at 15 USC \& 78aa-1 (1994).

39 Section 10 of the SEA provides: "It shall be unlawful for any person ... (b) To use or employ, in connection with the purchase or sale of any security ... any manipulative or deceptive device or contrivance in contravention of such rules and regulations as the Commission may pre- 
earlier case, Lampf, Pleva, Lipkind, Prupis \& Petigrow v Gilbertson, held that actions under Section 10(b) must be brought within one year of the discovery of the facts giving rise to the claim and within three years from when the cause of action accrued. ${ }^{41}$ Prior to Lampf, the federal courts had generally looked to state statute of limitation rules, many of which gave plaintiffs more time to file suits arising under the $\mathrm{SEA}^{42}$ As the decision in Lampf applied retroactively to all pending securities fraud actions, ${ }^{43}$ thousands of investors found their claims instantly time-barred. ${ }^{44}$ In response to Lampf, Congress added Section $27 \mathrm{~A}$ to the SEA, which allowed all claims pending at the time of Lampf to be adjudicated under pre-Lampf law.

In Plaut, the Supreme Court found Section 27A to be an unconstitutional violation of the separation of powers doctrine. ${ }^{46}$ Writing for the six-member majority, Justice Scalia emphasized three lines of reasoning. First, Scalia discussed the Framers' intent: "The Legislature would be possessed of power to 'prescrib[e] the rules by which the duties and rights of every citizen are to be regulated,' but the power of ' $[t]$ he interpretation of the laws' would be 'the proper and peculiar province of the courts." ", Second, the decision emphasized that even though Congress had not enacted Section 27A due to improper motives such as individual favoritism, the bottom line was that Congress - was still impermissibly interfering with judicial judgments. ${ }^{48}$ Finally,

scribe as necessary." Securities Exchange Act of 1934, 48 Stat 881, 891, codified at 15 USC $\S 78$ j (1994).

40501 US 350 (1991).

41 Id at 364.

42 See Charles H. Sturdy, Note, Section 27 A Confronts Lampf and the Constitution, 74 BU L Rev 645, 645-46 (1994) (stating that in Lampf the "Supreme Court abruptly reversed this practice" of federal courts "borrow[ing] the forum state's most analogous time limitation"). See also Patrick T. Murphy, Note, Section 27A of the SEA: An Unplugged Lampf Sheds No Constitutional Light, 78 Minn L Rev 197, 198-200 (1993) (noting that Lampf established a uniform litigation period under the SEA and ended the practice of courts borrowing state statute of limitation rules).

43 See James B. Beam Distilling Co v Georgia, 501 US 529 (1991) (decided on the same day as Lampf, holding that new rules of law must be applied to all other similarly situated litigants not barred by procedural requirements or res judicata).

44 See Sturdy, Note, 74 BU L Rev at 646 (cited in note 42).

45 Section 27A states in part: "Any private civil action implied under section 10(b) of this Act that was commenced on or before June 19, 1991-(1) which was dismissed as time barred subsequent to June 19,1991 , and (2) which would have been timely filed under the limitation period provided by the laws applicable in the jurisdiction ... as such laws existed on June 19,1991, shall be reinstated on motion by the plaintiff not later than 60 days after the date of enactment of this section." 105 Stat 2387 (1991), codified at 15 USC $\$ 78$ aa-1 (1994).

46 Plaut, 514 US at 240 (holding Section 27A unconstitutional "to the extent that it requires federal courts to reopen final judgments entered before its enactment").

47 Id at 222, quoting Federalist 78 (Hamilton) (discussing the Framers' intent to give the legislature the power to prescribe laws and courts the power to interpret laws).

48 Plaut, 514 US at 228 ("The prohibition is violated when an individual final judgment is legislatively rescinded for even the very best of reasons, such as the legislature's genuine convic- 
Justice Scalia focused on the absence of precedent for the statute at issue. He argued that the Court knew of no other instance in which Congress had tried to reopen final judgments by retroactive legislation and that the "prolonged reticence would be amazing if such interference were not understood to be constitutionally proscribed." $"$

Overall, the Court's argument centered on the idea that clear lines need to be drawn between the functions of the legislative and judicial branches. Justice Scalia aggressively criticized the case-specific approach advocated in Justice Breyer's concurrence:

[T] he doctrine of separation of powers is a structural safeguard rather than a remedy to be applied only when specific harm, or risk of specific harm, can be identified.... [I]t is a prophylactic device, establishing high walls and clear distinctions because low walls and vague distinctions will not be judicially defensible in the heat of interbranch conflict. ${ }^{\text {so }}$

However, in a brief aside, Scalia acknowledged an exception to his "high walls and clear distinctions": Congress may legislate to alter the "prospective effect of injunctions entered by Article III courts." The Plaut opinion explicitly states that Wheeling Bridge distinguishes itself and that "nothing in our holding today calls [it] into question," although the opinion offers no analysis for why this should be so. Going forward, Plaut gives the lower courts no guidance, as it simply reaffirms the Wheeling Bridge exception without explanation. ${ }^{s 3}$

\section{The Prison Litigation Reform Act: A Modern Application of Wheeling Bridge}

Knowing how to apply the Wheeling Bridge exception has become no less important as time has passed. For example, in 1996, President Clinton signed the Prison Litigation Reform Act of 1995 ("PLRA") into law. The purposes of the Act were to curb frivolous prisoner suits by reforming the process through which prisoners file civil actions, and to end overly intrusive intervention by the federal judiciary in the management of prisons by constraining legal remedies such as consent decrees. ${ }^{\text {ss }}$ Under the PLRA, consent decrees that in-

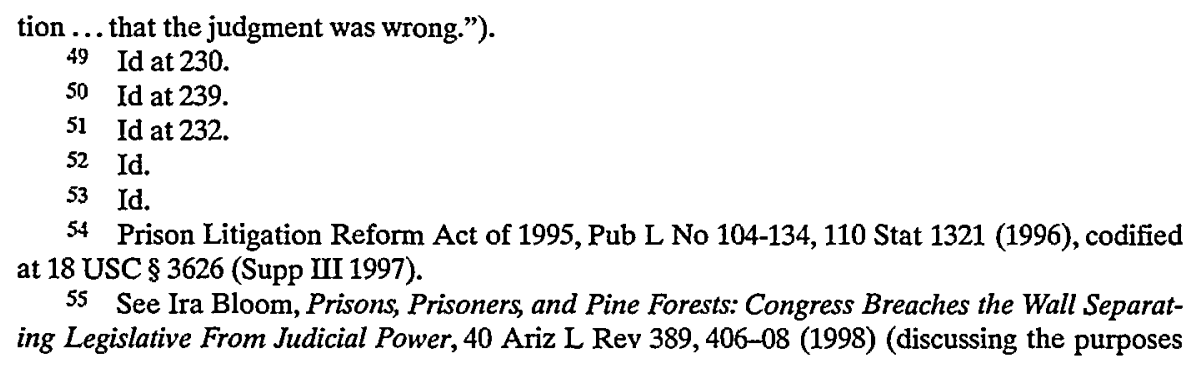

55 See Ira Bloom, Prisons, Prisoners, and Pine Forests: Congress Breaches the Wall Separating Legislative From Judicial Power, 40 Ariz L Rev 389, 406-08 (1998) (discussing the purposes 
mates have won against the defendant prisons are subject to immediate termination unless the court determines that the prospective relief was narrowly drawn, necessary to correct the violation of a federal right, and the least intrusive means of redressing the violation. ${ }^{56}$

The PLRA requirements have a huge impact on existing prison consent decrees. As most of the defendant prisons entered into the consent decrees because they did not want to admit any constitutional violations, almost all of these consent decrees can be terminated under the PLRA. ${ }^{\text {st }}$

How courts apply the Wheeling Bridge exception in PLRA cases is critical to the outcome of those cases. If courts find that the PLRA is constitutional because Wheeling Bridge dictates that Congress may reopen prospective final judgments such as consent decrees, the inmates lose. If courts find the Wheeling Bridge exception does not apply, the inmates win. The majority of circuits have found that the PLRA's termination provision falls within the Wheeling Bridge exception and, therefore, is constitutional. ${ }^{s 8}$ One panel of the Ninth Circuit

of the Prison Litigation Reform Act, which were to end "overly intrusive intervention by the federal judiciary" and to curb "frivolous inmate litigation"); Deborah Decker, Comment, Consent Decrees and the Prison Litigation Reform Act of 1995: Usurping Judicial Power or Quelling Judicial Micro-Management?, 1997 Wis L Rev 1275, 1275-76 (discussing purposes of the Prison Litigation Reform Act and noting that it "strikes out hard against consent decrees" and the " $\mathrm{ju}$ dicial micro-management' of prisons").

56 The Prison Litigation Reform Act $\S 802(b)(2), 110$ Stat at 1321-68, codified at 18 USC $\S 3626(\mathrm{~b})(2)$, states:

"Immediate Termination of Prospective Relief.-In any civil action with respect to prison conditions, a defendant or intervener shall be entitled to the immediate termination of any prospective relief if the relief was approved or granted in the absence of a finding by the court that the relief is narrowly drawn, extends no further than necessary to correct the violation of the Federal right, and is the least intrusive means necessary to correct the violation of the Federal right."

As no court could have anticipated the requirements of the PLRA before it was passed, section 802(b)(2) of the PLRA seems to give defendant prisons grounds to have virtually all inmate consent decrees immediately terminated. However, the PLRA does put some limitation on this. If the defendant prison moves to have a consent decree immediately terminated, the consent decree will continue to operate if the court makes specific written findings based on the record that the prospective relief conforms to the PLRA's requirements. 18 USC $\$ 3626(b)(3)$. If the court does not make a written finding in the form of a final order within thirty days of the motion for termination, the court must stay the consent decree's operation until it makes its ruling. 18 USC $\S 3626(\mathrm{e})(2)$.

57 The PLRA forbids awarding prospective relief unless there is a finding that a federal right has been violated. 18 USC $\$ 3626$ (b)(2). See Bloom, 40 Ariz L Rev at 409-10 (cited in note 55) (noting that "many prison consent decrees entered into throughout the nation can now be aborted" because prisons entered into them to avoid admitting constitutional violations). Of course, inmates retain all constitutional protections.

58 See Imprisoned Citizens Union v Ridge, 169 F3d 178, 183-87 (3d Cir 1999) (holding that PLRA falls within the Wheeling Bridge exception and does not "impermissibly mandate the reopening of final judgments"); Berwanger $v$ Cottey, 178 F3d 834, 839 (7th Cir 1999) (joining the overwhelming majority of circuits in holding that 18 USC $\$ 3626$ (b)(2) may constitutionally be applied to existing consent decrees); Benjamin v Jacobson, 172 F3d 144, 162-63 (2d Cir 1999) (en 
has found the PLRA unconstitutional..$^{59}$ However, an en banc Ninth Circuit subsequently vacated the decision of the panel on the grounds that the consent decree at issue was moot. ${ }^{60}$

The PLRA litigation illustrates what is at stake in allowing Congress to reopen final judgments that have prospective effects. If the Wheeling Bridge exception broadly applies to any case in which a court has granted prospective relief, injunctive remedies and consent decrees are vulnerable to congressional will. That is a substantial exception to Scalia's "high walls and clear distinctions" holding in Plaut, and it is reasonable to question whether he meant to pack such a powerful qualifier into a single sentence. Plus, there are additional arguments against the exception. From the Framers' perspective, it seems as though the Wheeling Bridge exception violates the notion of giving the legislature less power vis-à-vis the other branches instead of more. ${ }^{61}$ And on a practical level, the doctrine makes equitable relief considerably less attractive relative to damages. Parties may be much less likely to enter into consent decrees if they know that retroactive legislation can terminate or change the terms of their agreement. As consent decrees cut down on litigation costs by encouraging settlement, any decrease in their use could represent a harm to society. ${ }^{62}$

banc) (holding the PLRA constitutional because it only requires termination of prospective relief and "expressly excludes compensatory monetary damages"); Hadix v Johnson, 133 F3d 940, 942-43 (6th Cir 1998) (holding that prospective equitable relief in consent decrees remained subject to subsequent changes in the law made by the PLRA); Dougan v Singletary, 129 F3d 1424,1426 (11th Cir 1997) (holding that PLRA termination provision does not violate the separation of powers because the consent decrees the PLRA requires courts to review "are not final judgments for separation-of-powers purposes"); Inmates of Suffolk County Jail $v$ Rouse, 129 F3d 649, 656-57 (1st Cir 1997) (holding that the PLRA does not violate the separation of powers because "Plaut and Wheeling Bridge, read together, teach that ... the separation of powers principle permits[ ] legislatures to direct that courts respond to changes in substantive law by revisiting forward-looking injunctions"); Gavin v Branstad, 122 F3d 1081,1089 (8th Cir 1997) (holding that the PLRA does not amount to an attempt by Congress to impermissibly "reopen final judgments of Article III courts"); Plyler v Moore, 100 F3d 365, 371-72 (4th Cir 1996) (holding that the inmate consent decree was akin to an injunction and thus was "subject to subsequent changes in the law" made by the PLRA).

59 Taylor v United States, 143 F3d 1178, 1183 (9th Cir 1998) (distinguishing Wheeling Bridge on the ground that the PLRA does not effect a change in the "substantive" law that gave rise to the consent decree, but merely defines "the scope and nature of the remedy that [Congress] finds appropriate for prisoners who claim constitutional violations").

60 Taylor v United States, 181 F3d 1017, 1025-26 (9th Cir 1999) (en banc) (declining to express view "one way or the other" on cases from other circuits holding that the immediate termination provision of the PLRA is constitutional because the consent decree at issue in Taylor was moot but suggesting it would have held the PLRA unconstitutional if it had reached the issue).

61 See notes 7 and 10.

62 Note that in the case of the PLRA, the legislation may be at cross-purposes with itself. The PLRA made it much more difficult for inmates and prisons to enter into consent decrees as the PLRA requires that the defendant prisons admit to a violation of a federal right. See 18 USC $\S 3626$ (b)(2). This may result in the defendant prisons litigating cases they would have settled prior to the passage of the PLRA in order to avoid admitting constitutional violations. See 
On the other side of the debate, however, is the fact that the Wheeling Bridge exception has been around for almost one hundred and fifty years and used consistently (although not reasoned consistently) throughout that period. Even Justice Scalia, both a formalist and textualist, ${ }^{63}$ took the exception so for granted that in Plaut it only merited a sentence. Although the Court has not convincingly articulated its reasons for why and when Wheeling Bridge should apply, one has the suspicion that there is a melody within the notes.

This Comment's position is that the Wheeling Bridge exception is necessary to preserve one of the Constitution's underlying valuesequality before the law. The Comment argues that Wheeling Bridge should apply when a court's final judgment has prospective effects, so long as Congress's legislation does not violate any independent constitutional bar. This basically boils down Justice Nelson's three arguments from Wheeling Bridge II into a two-part test for when the exception applies-Congress must have the power under the Constitution to pass the legislation and the judgment must have prospective effects. The public/private rights analysis falls by the wayside as unnecessary and unclear.

\section{WHY WHEELING BRIDGE IS NECESSARY: PROMOTING EQUALITY BEFORE THE LAW}

No court has clearly articulated why the Wheeling Bridge exception should be applied to any judgment, regardless of whether the judgment concerns a "public right" or is executory in nature. Given the fact that the Wheeling Bridge exception requires Congress to intrude on the traditional province of the judiciary and the Supreme Court's continued commitment to the separation of powers doctrine in Plaut, it is surprising that courts have not spelled out their rationale for applying the exception. The courts all seem to share the same intuition that Wheeling Bridge promotes some underlying value that justifies lowering the "high walls" of separation of powers. This Comment argues that the Wheeling Bridge exception is necessary to promote equality before the law, one of the Constitution's core values.

\footnotetext{
Decker, Comment, 1997 Wis L Rev at 1319 (cited in note 55) (stating that "[a]s unjust as it may seem, the PLRA dictates that defendants would be wiser to litigate the case with the hopes that the violation will not be proven by the plaintiffs in court"). Flying in the face of this outcome, one of the stated purposes of the PLRA was to reduce prisoner litigation. Decker, Comment, 1997 Wis L Rev at 1275-76 (noting that the PLRA was "[c]hampioned" as a way of "curbing frivolous prisoner litigation by reforming the process through which prisoners file civil suits").

63 For a general discussion, see Autumn Fox and Stephen R. McAllister, An Eagle Soaring: The Jurisprudence of Justice Antonin Scalia, 19 Campbell L Rev 223 (1997) (discussing the jurisprudence of Justice Scalia, including his formalist and textualist approaches).

64 See note 34.

65 Plaut, 514 US at 239. See text accompanying note 50.
} 
The Framers' concern with separation of powers stemmed from their belief that "[t]he accumulation of all powers, legislative, executive, and judiciary, in the same hands, ... may justly be pronounced the very definition of tyranny." ers thought it "evident that none of [the branches] ought to possess, directly or indirectly, an overruling influence over the others." lowing Congress to reopen the final judgments of Article III courts when the judgments have executory effects would seem to violate this fundamental principle.

The Wheeling Bridge exception, however, rests on the idea that the whole purpose of the separation of powers doctrine is to ensure a government free from tyranny, a government in which "uniform laws confer [ ] equal rights on all, as distinguished from a government of men conferring unequal privileges on some." The Constitution was structured around the guiding principle that "all men are created equal" and contains the mandate that no person may be denied the "equal protection" of the laws. The Wheeling Bridge exception has been consistently accepted and applied by courts because it promotes this equality before the law. Wheeling Bridge ensures that all men at any one time are governed by the same uniform laws and (theoretically) may receive the same uniform justice from the courts.

\section{A. Preserving a Delicate Balance}

Although the Framers' saw the judiciary as the "least dangerous" branch, this conception was based on the judiciary remaining "truly

66 Federalist 47 (Madison), in Rossiter, ed, The Federalist Papers at 301 (cited in note 1).

67 Federalist 48 (Madison), in Rossiter, ed, The Federalist Papers at 308 (cited in note 1).

68 Santa Rita Oil Co $v$ State Board of Equalization, 112 Mont 359, 116 P2d 1012, 1017 (1941) (discussing the American theory of government as "uniform laws conferring equal rights on all"). The Supreme Court has traditionally considered equality before the law to be one of the fundamental rights guaranteed to U.S. citizens. See Permoli $v$ Municipality No 1 of the City of New Orleans, 44 US ( 3 How) 589, 597 (1845) (stating that "[e]quality before the law is the very essence of liberty"); Slaughter-House Cases, 83 US (16 Wall) 36,113 (1872) (Bradley dissenting) ("If a man be denied full equality before the law, he is denied one of the essential rights of citizenship as a citizen of the United States."). The modern Court still adheres to this principle. See Plyler v Doe, 457 US 202, 219 (1982) (characterizing the United States as a "Nation that prides itself on adherence to principles of equality under law").

69 United States Declaration of Independence (1776). In the Senate debate preceding the Fourteenth Amendment's adoption, Senator Howard stated:

[The Fourteenth Amendment] establishes equality before the law, and it gives the humblest, the poorest, the most despised of the race the same rights and the same protection before the law as it gives to the most powerful, the most wealthy, or the most haughty. That, sir, is republican government, as I understand it, and the only one which can claim the praise of a just Government.

Cong Globe, 39th Cong, 1st Sess 2766 (1866) (statement of Sen Howard).

70 US Const Amend XIV, $\$ 1$. 
distinct" from the legislature and the executive." As Alexander Hamilton argued, "liberty can have nothing to fear from the judiciary alone, but would have everything to fear from its union with either of the other departments." ${ }^{\prime 2}$ So although the Framers wanted to ensure that Congress did not overstep its boundaries into the judicial province, they were equally concerned that the judiciary not intrude on the legislature's province.

In combination with Plaut, the Wheeling Bridge exception ensures this balance. Under Plaut, Congress may not overrule the courts when their judgments govern solely past conduct. Similarly, Wheeling Bridge dictates that the courts may not overrule Congress when the courts' judgments purport to govern future conduct. The courts only have the power of "[t] he interpretation of the laws," not the power to make the laws. ${ }^{75}$ It remains to the legislature to "prescrib[e] the rules by which the duties and rights of every citizen are to be regulated." If it were otherwise, a court would be able to annul a congressional act as it applied to certain individuals through "prophetic discernment," leading to the same evils courts are so concerned about when Congress is perceived to be overreaching. ${ }^{78}$

By applying the Wheeling Bridge exception, courts ensure that all individuals are subject to the same laws at the same time. If the excep-

71 Federalist 78 (Hamilton), in Rossiter, ed, The Federalist Papers at 465-66 (cited in note 1).

72 Id at 466. See also note 11.

73 See notes 7 and 11.

74 Plaut, 514 US at 222, quoting Federalist 78 (Hamilton).

75 Obviously, courts make law through judicial decisions all the time. See United States $v$ Little Lake Misere Land Co, 412 US 580, 593 (1973), quoting Paul J. Mishkin, The Variousness of "Federal Law": Competence and Discretion in the Choice of National and State Rules for Decision, 105 U Pa L Rev 797, 800 (1957) ("At the very least, effective Constitutionalism requires recognition of power in the federal courts to declare, as a matter of common law or 'judicial legislation,' rules which may be necessary to fill in interstitially or otherwise effectuate the statutory patterns enacted in the large by Congress"). See also Michael B. Dashjian, The Prospective Application of Judicial Legislation, 24 Pac L J 317, 368-92 (1993) (discussing how the judiciary creates law and that this "judicial legislation" should be subject to prospective application). The difference is whether or not Congress has passed a statute purporting to govern the situation at hand. Laws made pursuant to the Constitution become the "supreme Law of the Land," which judges take an oath to uphold. US Const Art VI, cl 2. The judiciary's role is to "say what the law is," because "[t]hose who apply the rule to particular cases, must of necessity expound and interpret that rule." Marbury v Madison, 5 US (1 Cranch) 137, 177 (1803). However, interpreting the law in order to apply it in accordance with Congress's will is a far cry from annulling a constitutional statute through judicial decision.

76 Plaut, 514 US at 222, quoting Federalist 78 (Hamilton).

77 Fleming $v$ Rhodes, 331 US 100, 107 (1947) (upholding federal legislation that prevented private landlords from enforcing previously obtained eviction judgments because to hold otherwise would allow a court's "prophetic discernment" to nullify the "paramount power of Congress"). See text accompanying notes 114-116.

78 See Plaut, 514 US at 228 ("Not favoritism, nor even corruption, but power is the object of the separation-of-powers prohibition."). 
tion were not applied, courts would be able to constrain individuals from engaging in lawful behavior. Reiterating the example laid out in the introduction: if Smith obtained an injunction against Jones, prohibiting Jones from building a bridge at height $\mathrm{H}$, and Congress subsequently declared all bridges at height $\mathrm{H}$ lawful, Jones would be prevented from engaging in actions that everyone else was lawfully allowed to do. Without Wheeling Bridge, the liberty of the individual is exposed to "arbitrary control" " because the lawful scope of an individual's future conduct is solely determined by the moment in time the court issues its executory decree even if Congress subsequently writes the law out of existence.

\section{B. Overcoming Traditional Concerns about Retroactive Legislation}

Traditionally, the Supreme Court has been hostile to retroactive legislation. ${ }^{80}$ This hostility stems from two main concerns. First, retroactive legislation raises elementary considerations of fairness - "individuals should have an opportunity to know what the law is and to conform their conduct accordingly." ${ }^{81}$ Retroactive legislation can upset individuals' reasonable expectations. Second, Congress may pass retroactive legislation knowing exactly who will benefit from it, giving rise to the concern that Congress will use retroactive legislation to punish disfavored individuals. ${ }^{.2}$ However, this Comment argues that allowing Congress to reopen the executory judgments of Article III courts does not raise either of these concerns.

As executory judgments govern future actions, when Congress passes legislation changing the regulation of those actions, individuals are immediately put on notice that their future actions may have to

79 See Federalist 47 (Madison), in Rossiter, ed, The Federalist Papers at 303 (cited in note 1) ("Were the power of judging joined with the legislative, the life and liberty of the subject would be exposed to arbitrary control, for the judge would then be the legislator. Were it joined to the executive power, the judge might behave with all the violence of an oppressor.").

80 See Plaut, 514 US at 225-26 (stating that the Court's decisions "have uniformly provided fair warning that [retroactive legislation] exceeds the powers of Congress"); Landgraf $v$ USI Film Products, 511 US 244, 265-75 (1994) (noting that the "presumption against retroactive legislation is deeply rooted in [Supreme Court] jurisprudence"). Note that the Constitution explicitly prohibits certain types of retroactive legislation. The Ex Post Facto Clause prohibits retroactive penal legislation, and the prohibition on bills of attainder prevents Congress from summarily punishing individuals for past conduct. US Const Art I, $\$ 9, \mathrm{cl} 3$.

81 Landgraf, 511 US at 265. See also Charles B. Hochman, The Supreme Court and the Constitutionality of Retroactive Legislation, 73 Harv L Rev 692, 692-93 (1960) (arguing that a fundamental reason why retroactive legislation is suspect is because "a person should be able to plan his conduct with reasonable certainty of the legal consequences").

82 See Landgraf, 511 US at 266 (noting that the legislature may be "tempted to use retroactive legislation as a means of retribution against unpopular groups or individuals"). See also Hochman, 73 Harv L Rev at 693 (cited in note 81) (noting that a reason for "hostility to retroactive legislation is that such a statute may be passed with an exact knowledge of who will benefit from it"). 
change. Congress is not penalizing individuals for any past actions, but merely requiring all citizens to obey the same law in future actions. Applying the Wheeling Bridge exception does not upset parties' reasonable expectations regarding an injunction or consent decree, as no one can have a reasonable expectation of becoming immune from the current law. Moreover, the Supreme Court has consistently reinforced this idea by holding that courts retain the power to modify both injunctions ${ }^{84}$ and consent decrees. ${ }^{85}$ Even the Federal Rules of Civil Procedure condition parties' expectations regarding the "finality" of injunctions and consent decrees by stating that a court may "relieve a party ... from a final judgment" when "it is no longer equitable that the judgment should have prospective application." "Hence, the Wheeling Bridge exception does not raise elementary considerations of fairness as individuals cannot reasonably expect their current conduct to be immune from current law.

The Wheeling Bridge exception also does not result in Congress passing legislation out of improper motives as the legislation does not "create[ ] a new obligation, impose[ ] a new duty, or attach [ ] a new disability"s7 to actions in the past, but only governs actions yet to occur. Congress, in effect, is not passing retroactive legislation because the legislation only governs future conduct-not past conduct. Impor-

83 The principle of equality before the law is one of the founding principles of our government. See United States Declaration of Independence (1776) (stating "all men are created equal"); US Const Amend XIV, § 1 (declaring no person may be denied the "equal protection" of the laws). Equality before the law has also been treated as one of an American citizen's fundamental rights by the Supreme Court. See note 68. Therefore, regardless of the existence of the Wheeling Bridge exception, no one can have a reasonable belief that she is immune from current law.

84 See Milk Wagon Drivers Union of Chicago $v$ Meadowmoor Dairies, 312 US 287, 298 (1941) ("The injunction which we sustain is 'permanent' only for the temporary period for which it may last. ... Familiar equity procedure assures opportunity for modifying or vacating an injunction when its continuance is no longer warranted."); Glenn v Field Packing Co, 290 US 177, 178-79 (1933) (holding that a federal court may modify an injunction when there is a change in the law by state judicial decision); United States $v$ Swift \& Co, 286 US 106, 114 (1932) ("A continuing decree of injunction directed to events to come is subject always to adaptation as events may shape the need.").

85 See System Federation No 91, Railway Employees' Department, AFL-CIO v Wright, 364 US 642, 651 (1961):

The parties cannot, by giving each other consideration, purchase from a court of equity a continuing injunction.... [J]ust as the adopting court is free to reject agreed-upon terms as not in furtherance of statutory objectives, so must it be free to modify the terms of a consent decree when a change in law brings those terms in conflict with statutory objectives.

See also Rufo v Inmates of Suffolk County Jail, 502 US 367, 391 (1992) (stating "a consent decree is a final judgment that may be reopened only to the extent that equity requires"); Coca-Cola Co v Standard Bottling Co, 138 F2d 788, 790 (10th Cir 1943) (affirming modification of consent decree because "changes since its rendition [were] of sufficient importance to warrant" modification).

86 FRCP 60(b).

87 Landgraf, 511 US at 269 (quoting Justice Story's definition of retrospective legislation). 
tantly, Wheeling Bridge may actually prevent the judiciary from acting out of improper motives by granting individuals "[i]mmunity from federal regulation" through "forehanded contracts." Taking the PLRA as an example, it can be argued that Congress knew exactly who would benefit from the legislation-prisons. However, this is true of any legislation Congress passes - someone always stands to benefit, while someone else always stands to lose. ${ }^{89}$ It is Congress' democratic pedigree that gives it the institutional competence to make those kinds of decisions - not the judiciary. If it were otherwise, a judge with life tenure who was deliberately insulated from political pressures would be able to immunize parties before the court from the voice (and law) of the people for any motive she saw fit. The Wheeling Bridge exception prevents the judiciary from circumscribing Congress's power by removing certain individuals from its reach, just as Congress cannot limit the judiciary's power by acting as a reviewing court.

Overall, then, it becomes clear why courts have applied the Wheeling Bridge exception while still claiming adherence to separation of powers. By promoting equality before the law, Wheeling Bridge actually promotes the underlying goal of the separation of powers doctrine, a government free from tyranny, while not raising any of the traditional concerns of retrospective legislation.

\section{WHEN THE WHEELING BRIDGE EXCEPTION SHOULD APPLY}

Although courts have applied the Wheeling Bridge exception throughout the years, courts have had difficulty explaining when the exception should apply. In his Wheeling Bridge opinion, Justice Nelson raised two possible justifications for allowing Congress to overrule the Court's injunction regarding the bridge. First, Nelson argued that Congress's act declaring the bridge a "lawful structure[ ]" annulled the final judgment of the Court because free navigation of the river was a "public right." Second, Nelson distinguished between legal and

88 Fleming $v$ Rhodes, 331 US 100, 107 (1947). See text accompanying notes 114-116. See also Paul J. Mishkin, Foreword: The High Court, the Great Writ, and the Due Process of Time and Law, 79 Harv L Rev 56, 62 (1965) (discussing how the power and prestige of the judiciary depends on the belief that judges are bound by a "fixed, overriding" body of law that they apply "impersonally as well as impartially" and that they have "no program of their own to advance").

89 Hostility to retroactive legislation stems in part from the fact that Congress may choose individuals to penalize for past conduct. Although Congress may also know who prospective legislation will benefit, there is one important difference-parties are put on notice with the new law that their future conduct will have to change. They are not punished for their past conduct. Note, however, that the Supreme Court has held that Congress may not constitutionally prescribe a rule of decision for a pending case. United States $v$ Klein, 80 US (13 Wall) 128, 146-48 (1871).

90 Wheeling Bridge II, 59 US at 431. 
equitable remedies, asserting that the court's judgment could be reopened because it was "executory, a continuing decree." Nelson never defined "public right," and he never articulated how the public/private right and legal/equitable factors should be balanced against one another in future cases. In applying the Wheeling Bridge exception, courts have differed over which factor is dispositive. ${ }^{92}$ This Comment contends that the executory nature of the remedy is dispositive, as "public rights" is not a stable category. In addition, when applying the Wheeling Bridge exception, courts should clearly articulate that the exception applies because it promotes equality before the law, instead of trying to justify the result through a vested rights or "finality" analysis. This has the advantage of providing a clear and simple test to both lower courts and future parties.

\section{A. The Instability of the "Public Rights" Factor}

For "public rights" to be a useful factor in deciding whether the Wheeling Bridge exception should apply, courts must be able to define consistently what "public rights" are. But Justice Nelson failed to provide a definition in his Wheeling Bridge opinion, and, moreover, his categorization of the case as one involving public rights contradicted the general understanding of "public rights" at that time. The precedents of the day defined public rights cases as suits between a citizen and the government, while private rights cases were simply suits be-

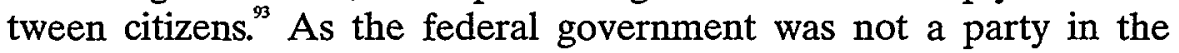
Wheeling Bridge case, the case did not fall in the traditional "public rights" category.

In modern cases, the Supreme Court has sent conflicting signals about its definition of "public rights," first giving a narrow definition that requires public rights "at a minimum arise "between the government and others," ${ }^{\text {,4 }}$ and later expanding the definition to equate public rights with some conception of public purpose. ${ }^{95}$ If the Supreme

91 Id.

92 See notes 34-35.

93 See Northern Pipeline Construction Co v Marathon Pipe Line Co, 458 US 50, 67-68 (1982), quoting Crowell v Benson, 285 US 22, 50 (1932) ("[The public rights doctrine] extends only to matters arising 'between the Government and persons subject to its authority in connection with the performance of the constitutional functions of the executive or legislative departments."); Murray's Lessee v Hoboken Land and Improvement Co, 59 US (18 How) 272, 283-84 (1855) (defining public wrongs as those in which the government occupies the same position as private persons in a case before the judiciary). See also J. Richard Doidge, Note, Is Purely Retroactive Legislation Limited by the Separation of Powers?: Rethinking United States v. Klein, 79 Cornell L Rev 910,958-59 (1994) (discussing how Justice Nelson did not employ traditional understandings of "public rights" in his Wheeling Bridge opinion).

94 See Northern Pipeline, 458 US at 69, quoting Ex Parte Bakelite Corp, 279 US 438, 451 (1929).

95 See Thomas v Union Carbide Agricultural Products Co, 473 US 568, 589 (1985) (stating 
Court consistently adopted the broad definition of public rightsequating public rights with public purpose-free navigation of the river in the Wheeling Bridge case would fit the definition, but the definition would be so broad as to become meaningless. As one commentator has pointed out:

Every matter of private law may, and generally does, involve some issue of public policy. There is merely a difference of remoteness. ... [I]n many fields of regulation public welfare or policy first makes its appearance in common-law adjudications of differences between individuals. This policy in the course of time may come to be enforced directly by an administrative agency or by criminal proceedings. But it would seem that the function of government performed is in both instances the same, namely, "that of promoting the public welfare by restraining and regulating the use of liberty and property."

With a broad definition of "public rights," courts would face a classic line-drawing problem in trying to determine whether a case involved public or private rights. This determination would be further complicated by the fact that although a public rights case would have to be associated with some public purpose, the individual plaintiff could be suing entirely for his own benefit. ${ }^{37}$ These definitional and line-drawing problems have caused one commentator to reject the public rights category as unstable and as providing "no useful foundation" for determining constitutional requirements."

Nelson's public rights argument can be reconciled with this Comment's position that the Wheeling Bridge exception should be applied when the judgment at issue involved executory relief. Nelson's "public rights" analysis can simply be collapsed into the requirement that Congress does not violate any other constitutional right. Since Congress could constitutionally regulate the navigation of the river

that the Federal Insecticide, Fungicide, and Rodenticide Act does not create a purely private right because portions of the legislation serve a "public purpose as an integral part of a program safeguarding the public health").

96 John Dickinson, Administrative Justice and the Supremacy of Law in the United States 28 n 49 (Russell \& Russell 1927).

97 See Hodges $v$ Snyder, 261 US 600, 604 (1923) ("[ $T$ ]he doctrine that a judgment declaring a public right may be annulled by subsequent legislation, applies with like force in the present suit, although brought by individuals primarily for their own benefit; the right involved and adjudged ... being public, and not private."); Wheeling Bridge II, 59 US at 431 ("But, although this right of navigation be a public right common to all, yet, a private party sustaining special damage by the obstruction may ... maintain an action at law against the party creating it, to recover his damages").

98 See Gordon G. Young, Public Rights and the Federal Judicial Power: From Murray's Lessee Through Crowell to Schor, 35 Buff L Rev 765, 864-65 (1986) (arguing that it is often "fruitless to attempt to distinguish between federal rights of action created or recognized primarily for private, individual benefit, and those created as incentives for private policing of public values"). 
under the Commerce Clause, ${ }^{99}$ the "public right" was both created and determined by the scope of that regulation. This argument is bolstered by the fact that Nelson repeatedly emphasized that public rights are "secured by acts of congress" and "under the regulation of congress."

Overall, the public/private rights analysis should be discarded as it does nothing to further equality before the law, the goal behind the Wheeling Bridge exception. The public/private rights analysis introduces unnecessary complexity into the question of when Wheeling Bridge should apply. Instead of having a clear test for when Congress may legislate to reopen the final judgment of an Article III court, the public/private rights analysis may allow some parties to immunize themselves from the law whenever they can convince a court that their case involves "private" rights. The Comment provides a clear test for lower courts to ensure that the Wheeling Bridge exception is applied consistently and in furtherance of the exception's underlying purpose, equality before the law.

\section{B. The Executory Nature of Relief:The Dispositive Factor}

Although Justice Nelson gave no explicit guidance as how to weigh the public right and executory relief factors, there is evidence in the Wheeling Bridge opinion that Justice Nelson did not find the public rights distinction sufficient, standing on its own, to require application of the exception. Nelson held that Congress could reopen the final judgment of the Court with respect to the executory portion of the decree, but that the award of costs to Pennsylvania must remain unchanged, even though the case was one of "public rights." to the conclusion that at a minimum, Justice Nelson thought executory relief was a necessary condition to trigger application of the Wheeling Bridge exception. Applying the exception in subsequent cases, courts have steadily attributed less significance to the public rights factor than to the executory nature of the relief. The subsequent Supreme Court cases that have focused on the public rights analysis when applying Wheeling Bridge were all cases that also involved executory relief. $^{102}$ Similarly, lower courts only have applied the Wheeling Bridge

99 See Wheeling Bridge II, 59 US at 431.

$100 \mathrm{Id}$.

101 Id at $431,436$.

102 See Hodges $v$ Snyder, 261 US 600, 604 (1923) (holding act of legislature consolidating several school districts constitutional even though the Supreme Court had previously permanently enjoined the consolidation); The Clinton Bridge, 77 US (10 Wall) 454, 462-63 (1870) (upholding act of Congress declaring bridge lawful even though suit to enjoin building of bridge was pending). 
exception when executory relief was at issue..$^{103}$ This makes sense when the underlying purpose of the Wheeling Bridge exception is taken into account. Because the purpose of the exception is to promote equality before the law, it is the executory nature of the judgment that becomes dispositive. Congress must have the ability to reopen judgments that govern parties' future conduct in order to bring that conduct in line with current law. This ensures that all parties are governed by the same law at the same time. The public/private rights distinction is irrelevant as it does nothing to promote this underlying goal.

Although courts have consistently held that there is no constitutional violation when the legislature reopens final judgments with executory effects, ${ }^{104}$ the opinions have not been consistently reasoned. The courts are all striving to articulate their underlying conviction that reopening executory judgments does not pose a constitutional problem, but their rationales are unsatisfying. Generally, courts have given one of two reasons for why executory judgments are susceptible to congressional will. Some courts have reasoned that no rights "vest" in executory judgments, ${ }^{105}$ while others have based their result on the idea that since courts have continuing power to modify or vacate executory decrees, the judgment is not "final."

103 See Mount Graham Coalition v Thomas, 89 F3d 554, 556-57 (9th Cir 1996) (holding that legislation authorizing particular area as site for telescope project did not violate separation of powers by overturning injunction environmental group had obtained to stop project); Georgia Association of Retarded Citizens v McDaniel, 855 F2d 805, 812 (11th Cir 1988) (holding that Wheeling Bridge exception did not apply because no equitable relief or public rights at issue); Daylo v Administrator of Veterans' Affairs, 501 F2d 811, 818 (DC Cir 1974) (holding damages judgment immune from congressional alteration); McGrath $v$ Potash, 199 F2d 166, 167-68 (DC Cir 1952) (vacating injunction against deportation hearings because Congress had removed the statutory basis for such injunction); Western Union Telegraph Co v International Brotherhood of Electrical Workers, $133 \mathrm{~F} 2 \mathrm{~d}$ 955, 958 (7th Cir 1943) (quoting Wheeling Bridge as precedent for requiring court to modify an injunction when congressional legislation had changed the underlying law).

104 See notes 102-103.

105 See, for example, Landgraf $v$ USI Film Products, 511 US 244, 273-74 (1994) (stating that "relief by injunction operates in futuro" and thus plaintiff has no "vested right" in the remedy); Georgia Association of Retarded Citizens, 855 F2d at 812 (stating that an executory decree affecting public rights was an exception to "the rule regarding rights which vest as a result of a judgment"); Daylo, $501 \mathrm{~F} 2 \mathrm{~d}$ at 818 (stating that Wheeling Bridge and its progeny are an exception to the general rule "that rights vest[ ] in final judgments"). See also Ladner v Siegel, $298 \mathrm{~Pa}$ 487, 148 A 699, 703 (1930) (finding that an injunction does not create any "vested right[s]" in the holder and therefore remains vulnerable to modification).

106 See, for example, Western Union at 957-58 (noting that when decree is of a continuous nature, "it is not final," and "will be vacated or modified where the law has been changed"). See also Coca-Cola Co v Standard Bottling Co, 138 F2d 788, 789 (10th Cir 1943) (stating that there "can be no doubt" that a court may "modify an injunctive decree"); Santa Rita Oil Co v State Board of Equalization, 112 Mont 359, 116 P2d 1012, 1016 (1941), citing Milk Wagon Drivers Union of Chicago v Meadowmoor Dairies, 312 US 287, 298 (1941) (stating the "injunction . . . is 'permanent' only for the temporary period for which it may last"). 
This Comment argues that courts should not justify the application of Wheeling Bridge in either of these ways, because neither explanation pinpoints Wheeling Bridge's underlying goal-equality before the law. Instead, courts should articulate that the Wheeling Bridge exception applies whenever a judgment has executory effects in order to ensure that all people are subject to the same law at the same time. This has the advantage of providing a clear and simple test to both lower courts and future parties. In addition, the proposed test does not significantly expand the scope of the exception, as it already conforms with the results of existing case law.

\section{The vested rights rationale.}

Some courts, including the Supreme Court, have argued that executory decrees are vulnerable to subsequent legislation because no rights "vest" in executory judgments. ${ }^{107}$ The modern vested rights doctrine has two constitutional components. The due process component posits that rights fixed by judgment are "form[s] of property over which legislatures have no greater power than any other," and the separation of powers component prevents Congress from sitting in review over judgments of the federal courts. ${ }^{108}$ The Supreme Court first articulated the idea that the legislature lacks the power to take away rights that have been "vested" by final judgment in an 1898 decision, McCullough v Virginia. ${ }^{109}$ Subsequent decisions by the Court have reaffirmed this principle. ${ }^{110}$

Even though the Court has explicitly avowed adherence to the vested rights doctrine, the Court has still concluded that executory judgments represent an exception to the rule. ${ }^{111}$ The Court has stated that "relief by injunction operates in futuro" and that no "vested right" inheres in an injunctive decree." The Court has never convinc-

107 See note 105.

108 Georgia Association of Retarded Citizens, $855 \mathrm{~F} 2 \mathrm{~d}$ at 810 . See also Johnston $v$ Cigna Corp, 14 F3d 486, 490-91 (10th Cir 1993) (discussing "twofold" nature of the "vested rights doctrine").

109172 US 102, 123-24 (1898) ("It is not within the power of a legislature to take away rights which have been once vested by a judgment. Legislation may act on subsequent proceedings, may abate actions pending, but when those actions have passed into judgment the power of the legislature to disturb the rights created thereby ceases.").

110 See, for example, Chicago \& Southern Air Lines, Inc $v$ Waterman Steamship Corp, 333 US 103, 113 (1948) ("Judgments within the powers vested in [Article III] courts ... may not lawfully be revised, overturned or refused faith and credit by another Department of Government."); Hodges, 261 US at 603 ("[T]he private rights of parties which have been vested by the judgment of a court cannot be taken away by subsequent legislation, but must be thereafter enforced by the court regardless of such legislation."); Stephens v Cherokee Nation, 174 US 445, 478 (1899) ("[I]t is undoubtedly true that legislatures cannot set aside the judgments of courts.").

111 See Landgraf, 511 US at 273.

112 Id at 274, quoting American Steel Foundries v Tri-City Central Trades Council, 257 US 
ingly explained, in a case applying the Wheeling Bridge exception, why this should be. In a case analogous to Wheeling Bridge, however, the Court has been more persuasive. In Fleming $v$ Rhodes, ${ }^{113}$ the Court sustained federal legislation that prevented private landlords from enforcing previously obtained eviction judgments against private tenants. ${ }^{14}$ The landlords claimed the legislation violated their "vested rights" in the prior state court judgments. "Strangely, the Court never mentions Wheeling Bridge, but holds that the landlords have no vested rights in the judgment, stating:

Federal regulation of future action based upon rights previously acquired by the person regulated is not prohibited by the Constitution. So long as the Constitution authorizes the subsequently enacted legislation, the fact that its provisions limit or interfere with previously acquired rights does not condemn it. Immunity from federal regulation is not gained through forehanded contracts. Were it otherwise the paramount powers of Congress could be nullified by "prophetic discernment." The rights acquired by judgments have no different standing.

The Court is concerned that the judiciary will overstep its boundaries and impinge on Congress' power by nullifying the impact of a new law through "prophetic discernment." But this still leaves a basic question unanswered: If separation of powers is so important, why is the Court not concerned about allowing Congress to intervene on the judiciary's province when the judgment is executory? The answer is that the Wheeling Bridge exception promotes equality before the law. By reopening the final judgments of Article III courts that are executory in nature, Congress is able to bring parties' future conduct in line with current law. This ensures that all people are subject to the

184,201 (1921).

113331 US 100 (1947).

114 Id at 106-07 (holding that injunctions against landlords enforcing previously obtained eviction judgments in the future should be sustained because of changes in the controlling law).

115 Id at 106.

116 Id at 107 (citations omitted). See also Ladner $v$ Siegel,298 Pa 487, 148 A 699, 704 (1930) (holding that a court of equity has the power to modify an injunction protecting property). In Ladner, the Supreme Court of Pennsylvania stated:

An injunction decree does not create a right; it protects the right of the owner to the enjoyment of his property from injurious interference by the uses of other land. The right protected is an attribute of property existing through the application of common-law principles. A decree preventing its injury does not give to the complaining party a perpetual or vested right either in the remedy, the law governing the order, or the effect of it. He is not entitled to the same measure of protection at all times and under all circumstances. A decree protecting a property right is given subject to the rules governing modification, suspension, or dissolution of an injunction. The decree is an ambulatory one, and marches along with time affected by the nature of the proceeding. 
same laws at the same time, one of the underlying goals of separation of powers. ${ }^{117}$

2. The finality analysis.

A related line of reasoning is that because a court retains the power to revoke or modify an injunction, the executory judgment is not really final. ${ }^{118}$ The Supreme Court has held in several decisions that courts retain the power to modify or revoke injunctions. ${ }^{119}$ From this, courts reason that "though a decree may be final as it relates to an appeal," when the "proceedings are of a continuing nature, it is not final, ... and the injunction will be vacated or modified where the law has been changed making acts enjoined legal." ${ }^{120}$ One court characterized the class of injunctions open to amendment as "'legislative' in function" because they "attempt[ed] to control the legal status of ... future actions." ${ }^{121}$

When applying the Wheeling Bridge exception in the context of consent decrees, the Supreme Court has used the same "finality" analysis. Because courts retain the power to modify or revoke consent decrees, consent decrees are not truly final; therefore, applying the Wheeling Bridge exception does not violate the separation of powers. ${ }^{12}$ The fact that a consent decree is at issue, rather than an injunction, makes no difference in the analysis. ${ }^{123}$ To courts, the argument that executory decrees are not really "final" seems to make common sense. ${ }^{124}$ This is intuitive when one considers the underlying value of the Wheeling Bridge exception-promoting equality before the law. In order for all citizens to be subject to the same law at the same time, parties must not be allowed to gain immunity from the law through the courts in the form of an executory decree.

117 See Part II.

118 See note 106.

119 See note 84.

120 Western Union Telegraph Co $v$ International Brotherhood of Electrical Workers, 133 F2d 955, 957 (7th Cir 1943).

121 Daylo v Administrator of Veterans' Affairs, 501 F2d 811, 818 (DC Cir 1974).

122 See note 85 .

123 See United States $v$ Swift \& Co, 286 US 106, 114-15 (1932) ("The result is all one whether the decree has been entered after litigation or by consent.'.. We reject the argument ... that a decree entered upon consent is to be treated as a contract and not as a judicial act."). See also the discussion of courts that have found the modification of consent decrees under the PLRA constitutional in note 58 and accompanying text.

124 See Santa Rita Oil Co v State Board of Equalization, 112 Mont 359, 116 P2d 1012, 1017 (1941) (declaring "obviously it is not equitable to continue to restrain a party from actions no longer unlawful whether the change in law has come about through new legislative enactment or through an authoritative change in judicial construction by the courts").

125 See Part II. 
This Comment does not argue that when courts use the finality analysis to justify Wheeling Bridge that they are wrong, but simply imprecise. The finality analysis does not clearly articulate the Wheeling Bridge exception's goal-equality before the law-thereby unnecessarily complicating the analysis. Both courts and parties would be better served by a clear and simple articulation of the test. Wheeling Bridge applies to all executory judgments in order to ensure all persons are subject to the same law at the same time.

Courts should refrain from relying on a vested rights or finality justification in applying Wheeling Bridge because it obscures the real reason for the exception. Congress may reopen the executory judgments of an Article III court not because no rights vest in the judgment or the judgment is not final, but because Congress must be allowed to bring parties' future conduct in line with current law. By clearly articulating the underlying goal of the Wheeling Bridge exception, courts provide a clearer and simplified test for when the exception applies.

\section{CONCLUSION}

Although courts have used the Wheeling Bridge exception for almost one hundred and fifty years, courts have had great difficulty in articulating exactly when and why the exception should apply. This Comment argues that Wheeling Bridge should apply whenever a judgment has executory effects, regardless of whether the case involved a public or private right. This position has the advantage of promoting equality before the law, providing a clear test to lower courts, and conforming with the result of existing case law. This Comment contends that by promoting equality before the law, Wheeling Bridge preserves the balance of power between the judiciary and the legislature. Congress may not overrule the courts when their judgments govern solely past conduct, and the courts may not overrule Congress when the courts' judgments purport to govern future conduct. Therefore, the Wheeling Bridge exception can be reconciled with Scalia's opinion in Plaut, as one function of Wheeling Bridge is to maintain the "high walls and clear distinctions" ${ }^{\text {"126 }}$ the Court is committed to protecting. 


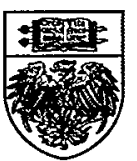

